\title{
OS TERRENOS TECTÔNICOS DA FAIXA RIBEIRA NA SERRA DA BOCAINAE NA BAÍA DA ILHA GRANDE, SUDESTE DO BRASIL
}

\author{
LUIZ GUILHERME DO EIRADO ${ }^{1}$, MONICA HEILBRON ${ }^{2} \&$ \\ JULIO CESAR HORTA DE ALMEIDA²
}

\begin{abstract}
Resumo Quatro unidades tectônicas compõem o segmento central da Faixa Ribeira na Serra do Mar, entre os estados do Rio de Janeiro e São Paulo: terrenos Ocidental, Oriental, Paraíba do Sul e Embu. O Terreno Ocidental corresponde à margem retrabalhada do Cráton do São Francisco, representado pelas rochas metassedimentares da Megassequência Andrelândia. O Terreno Oriental compreende o arco magmático Rio Negro, formado pela subducção oceânica da placa São Francisco. O Terreno Paraíba do Sul é composto pelos ortognaisses paleoproterozóicos do Complexo Quirino e pelas rochas metassedimentares do Grupo Paraíba do Sul, enquanto o Terreno Embu é formado por uma sucessão supracrustal (Complexo Embu) e ortognaisses do Complexo Taquaral de idade indefinida. Rochas granitóides sin a pós-colisionais intrudem todos terrenos. O evento de deformação principal gerou o empilhamento tectônico dos terrenos durante a etapa colisional (ca. $580 \mathrm{Ma}$ ) da Orogênese Brasiliana, quando o Terreno Ocidental foi cavalgado pelos demais. A origem e paleogeografia dos terrenos Paraíba do Sul e Embu são indefinidas, mas podem estar relacionados ao arco magmático brasiliano.
\end{abstract}

Palavras-chaves: Faixa Ribeira, Orogênese brasiliana, lito-estratigrafia, geologia estrutural, sudeste do Brasil

\begin{abstract}
THE TECTONIC TERRANES OF THE RIBEIRA BELT IN BOCAINA RANGE AND ILHA GRANDE BAY, SOUTHEASTERN BRAZIL. The central segment of the Neoproterozoic Ribeira belt in the studied area is composed of four tectonic units: the Occidental, Oriental, Paraíba do Sul and Embu terranes. The metasedimentary sequence of the Occidental Terrane represents the reworked margin of the São Francisco Craton. The Oriental Terrane comprises the cordilleran magmatic arc that collided with the São Francisco Plate at ca. 580 Ma. The Paraíba do Sul Terrane is composed of Paleoproterozoic orthogneisses and metasedimentary rocks, and the Embu Terrane comprises supracrustal succession and undated orthogneisses. Granitoid rocks intrude all terranes. These terranes were thrust-stacked during the main deformational phase related to the collisional stage of the Brasiliano Orogeny, when the Occidental Terrane was covered by the other ones. The nature and the paleogeography of the Paraíba do Sul and Embu terranes are unclear, but a relation to a magmatic arc environment can be suggested.
\end{abstract}

Keywords: Ribeira Belt, Brasiliano Orogeny, litho-stratigraphy, structural geology, southeastern Brazil

INTRODUÇÃO A Faixa Ribeira é uma das entidades do Sistema Orogênico Mantiqueira, formado pela aglutinação de parte do Gondwana Ocidental durante a Orogênese Brasiliana, entre o Neoproterozóico e o Cambriano. Por sua vez, a Faixa Ribeira compreende um conjunto de terrenos tectônicos empilhados sucessivamente sobre a margem do Cráton do São Francisco, resultado da interação deste paleocontinente com outra(s) (micro)placa(s) (Heilbron et al., 2004). Estes terrenos tectônicos apresentam, de maneira geral, associações litológicas, metamorfismo e estilos estruturais contrastantes.

Este trabalho visa contribuir para o conhecimento geológico do segmento central do Orógeno Ribeira na região da Serra da Bocaina e Baía da Ilha Grande, uma porção da Serra do Mar entre os estados do Rio de Janeiro e São Paulo (Fig. 1). Serão caracterizadas as unidades lito-estratigráficas e os estilos estruturais da deformação principal (sin-colisional) de cada terreno, bem como seus limites tectônicos. As rochas granitóides tardi a pós-colisionais e as estruturas relacionadas a esta etapa orogênica, serão abordadas em conjunto para todos os terrenos. Este estudo é baseado, principalmente, em dados coletados no mapeamento geológico na escala 1:50.000, aliado a análises estrutural e petrográfica.

\section{COMPARTIMENTAĈ̃O TECTÔNICA DA FAIXA RI-}

BEIRA O segmento central da Faixa Ribeira é constituído por cinco unidades tectônicas principais, limitadas por empurrões ou zonas de cisalhamento dúcteis oblíquas de alto ângulo: terrenos Ocidental, Oriental, Paraíba do Sul, Embu e Cabo Frio (Heilbron et al., 2000, 2004) (Fig. 1). Na área de estudo, afloram segmentos dos quatro primeiros terrenos, que estão relacionados a um primeiro estágio colisional, há ca. $580 \mathrm{Ma}$, enquanto o Terreno Cabo Frio só foi colado aos demais numa colisão tardia, há ca. $520 \mathrm{Ma}$, já no Cambriano (Trouw et al., 2000; Heilbron et al., 2004; Schmitt et al., 2004). O Terreno Ocidental representa a margem retrabalhada da paleoplaca São Francisco, enquanto os outros terrenos estão vinculados a(s) outra(s) placa(s) envolvidas nos estágios colisionais da Orogênese Brasiliana. O Terreno Oriental abrange o arco magmático formado na etapa pré-colisional.

As idades existentes das diversas unidades lito-estratigráficas desses terrenos, especialmente, as rochas do embasamento paleoproterozóico e granitóides brasilianos, foram, na medida do possível, correlacionadas às unidades da área estudada (Tabela 1). As rochas magmáticas brasilianas foram agrupadas em pré, sin, tardi e pós-colisionais, em relação ao primeiro estágio colisional da Faixa Ribeira (Heilbron et al., 2000; Heilbron \& Machado, 2003).

\section{UNIDADES LITO-ESTRATIGRÁFICAS DOS TERRE- NOS}

Terreno Ocidental As rochas do Terreno Ocidental afloram, principalmente, na escarpa atlântica da Serra da Bocaina e na zona costeira (Fig. 2). Na área abordada, este terreno é representado por uma sucessão metassedimentar de alto grau, cons-

1- TEKTOS - Grupo de Pesquisa em Geotectônica/UERJ; Programa de Pós-graduação em Análise de Bacias e Faixas Móveis, Faculdade de Geologia, Universidade do Estado do Rio de Janeiro (UERJ), Rua São Francisco Xavier 524/ 4026-A, CEP: 20550-090, Rio de Janeiro, RJ; e-mail: eirado@uerj.br. - *Endereço atual: Fundação Gorceix - PETROBRAS/ CENPES/ PDEXP/ GEOTEC, Av. Horácio Macedo, 950, Cidade Universitária - Ilha do Fundão, CEP 21941-915, Rio de Janeiro - RJ. 2- Departamento de Geotectônica e Geologia Regional, Faculdade de Geologia, Universidade do Estado do Rio de Janeiro (UERJ), Rua São Francisco Xavier 524/ 4020A, CEP: 20550-090, Rio de Janeiro, RJ; e-mails: heilbron@uerj.br, jcha@uerj.br 
tituída por granada-sillimanita-biotita gnaisse e biotita gnaisse bandado, migmatíticos, com freqüentes intercalações de ca- madas e lentes de rochas calcissilicáticas, quartzitos impuros, e raros gonditos. Este conjunto litológico é correlacionável às

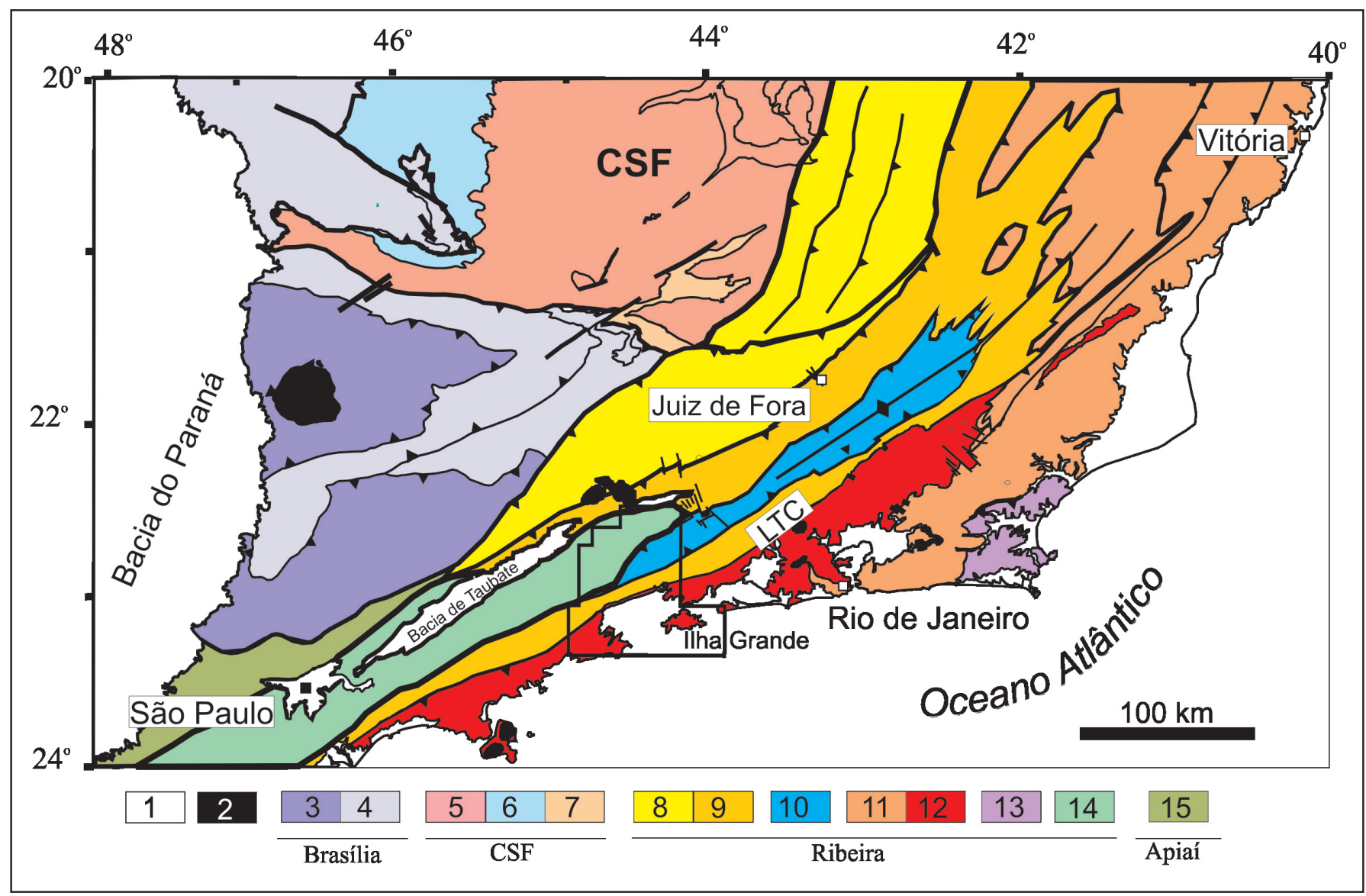

Figura 1-Mapa tectônico do sudeste brasileiro mostrando as principais unidades do setor central do Sistema Orogênico Mantiqueira e a localização da área de estudo (modificado de Heilbron et al., 2004). Legenda: 1) Bacia do Paraná e sedimentos cenozóicos; 2) rochas alcalinas do Cretáceo e Terciário; Orógeno Brasília: 3) nappes inferiores, 4) nappes superiores; Cráton do São Francisco (CSF): 5) embasamento, 6) Supergrupo São Francisco, 7) rochas metassedimentares do Domínio Autóctone; Orógeno Ribeira: 8 e 9) Terreno Ocidental (Domínios Andrelândia e Juiz de Fora), 10) Terreno Paraíba do Sul, 11) Terreno Oriental incluindo 12) arco magmático Rio Negro, 13) Terreno Cabo Frio, 14) Terreno Embu; 15) Orógeno Apiaí (Terreno São Roque). LTC-Limite Tectônico Central da Faixa Ribeira.

Tabela 1 - Unidades litológicas dos terrenos tectônicos da área de estudo e correlação com as idades U-Pb pré-existentes, disponíveis regionalmente.

\begin{tabular}{|c|c|c|c|c|c|}
\hline \multirow{2}{*}{$\begin{array}{l}\text { Tipo de rocha } \\
\text { (Período de tempo) }\end{array}$} & \multicolumn{4}{|c|}{ Compartimento Tectônico } & \multirow{2}{*}{$\begin{array}{c}\text { Idade U-Pb } \\
\text { Terreno: referência* }\end{array}$} \\
\hline & \begin{tabular}{|l|} 
Terreno Ocidental (TOC) \\
\end{tabular} & Terreno Embu (TEM) & Terreno Paraíba do Sul (TPS) & Terreno Oriental (TOR) & \\
\hline $\begin{array}{l}\text { Granitóides pós-colisionais } \\
(510-480 \mathrm{Ma})\end{array}$ & $\begin{array}{l}\text { Granito Mambucaba; } \\
\text { veios graníticos }\end{array}$ & Veios graníticos & Veios graníticos & $\begin{array}{l}\text { Granitos Vila Dois Rios, } \\
\text { Mambucaba, Mombaça; } \\
\text { veios graníticos }\end{array}$ & TOR: (1), (8) \\
\hline $\begin{array}{l}\text { Granitóides fracamente } \\
\text { foliados tardi-colisionais } \\
\text { (540-510 Ma) }\end{array}$ & Complexo Plutônico Parati & $\begin{array}{l}\text { Muscovita-biotita } \\
\text { leucogranito; Complexo } \\
\text { Plutônico Parati }\end{array}$ & $\begin{array}{l}\text { Muscovita-biotita leucogranito } \\
\text { Complexo Plutônico Parati }\end{array}$ & $\begin{array}{l}\text { Suíte Charnockítica Ilha Grande; } \\
\text { Complexo Plutônico Parati }\end{array}$ & $\begin{array}{l}\text { TOC, TPS: (1), (2) } \\
\text { TOR: (8) }\end{array}$ \\
\hline $\begin{array}{l}\text { Granitóides foliados sin- } \\
\text { colisionais } \\
(590-550 \mathrm{Ma})\end{array}$ & \begin{tabular}{|l|}
$\begin{array}{l}\text { Granada-biotita gnaisse } \\
\text { porfiróide; leucogranitos } \\
\text { foliados }\end{array}$ \\
\end{tabular} & $\begin{array}{l}\text { Granitos Campo Alegre, } \\
\text { Funil, leucogranitos foliados }\end{array}$ & $\begin{array}{l}\text { Granitos Bananal, Resgate e } \\
\text { leucogranitos foliados }\end{array}$ & $\begin{array}{l}\text { (hornblenda)-biotita gnaisse } \\
\text { porfiróide; } \\
\text { biotita leucognaisse } \\
\end{array}$ & $\begin{array}{l}\text { TOC, TPS: (1), (2) } \\
\text { TEM: (6), (7) } \\
\text { TOR: (3), (8) }\end{array}$ \\
\hline $\begin{array}{l}\text { Ortognaisses e granitóides } \\
\text { com posicionamento } \\
\text { indefinido }\end{array}$ & - & Complexo Taquaral & Granito Campinho & - & $\begin{array}{l}\text { TEM: (1) metamorfismo } \\
\text { sin-colisional }\end{array}$ \\
\hline $\begin{array}{l}\text { Granitóides foliados pré- } \\
\text { colisionais } \\
(790-600 \mathrm{Ma})\end{array}$ & - & - & - & $\begin{array}{l}\text { Ortognaisses do Complexo Rio } \\
\text { Negro }\end{array}$ & TOR: (3), (4), (8) \\
\hline $\begin{array}{l}\text { Sucessões } \\
\text { metassedimentares } \\
\text { (Neoproterozóico ?) }\end{array}$ & Megassequência Andrelândia & \begin{tabular}{|l} 
Complexo Embu: \\
Unidades Rio Guaripu e Rio \\
Paraitinga (topo)
\end{tabular} & \begin{tabular}{|l} 
Grupo Paraíba do Sul: \\
Unidades Três Barras, São João e \\
Beleza (topo)
\end{tabular} & - & - \\
\hline $\begin{array}{l}\text { Ortognaisses do } \\
\text { embasamento } \\
\text { (pré-1.8 Ga) }\end{array}$ & - & - & Complexo Quirino & - & TPS: (2) \\
\hline
\end{tabular}

Referências das idades U-Pb: (1) Machado et al., 1996; (2) Valladares et al., 1997; (3) Tupinambá, 1999; (4) Tupinambá et al., 2000; (5) Valladares et al., 2000; (6) Pereira et al., 2001; (7) Janasi et al., 2003; (8) Heilbron e Machado, 2003. 
associações de litofácies distais da Megassequência Andrelândia de idade neoproterozóica, inseridas no Domínio Juiz de Fora
(Fig. 1) (Paciullo et al., 2000). A base desta unidade, junto ao contato com o Terreno Oriental, é marcada pela forte alternância

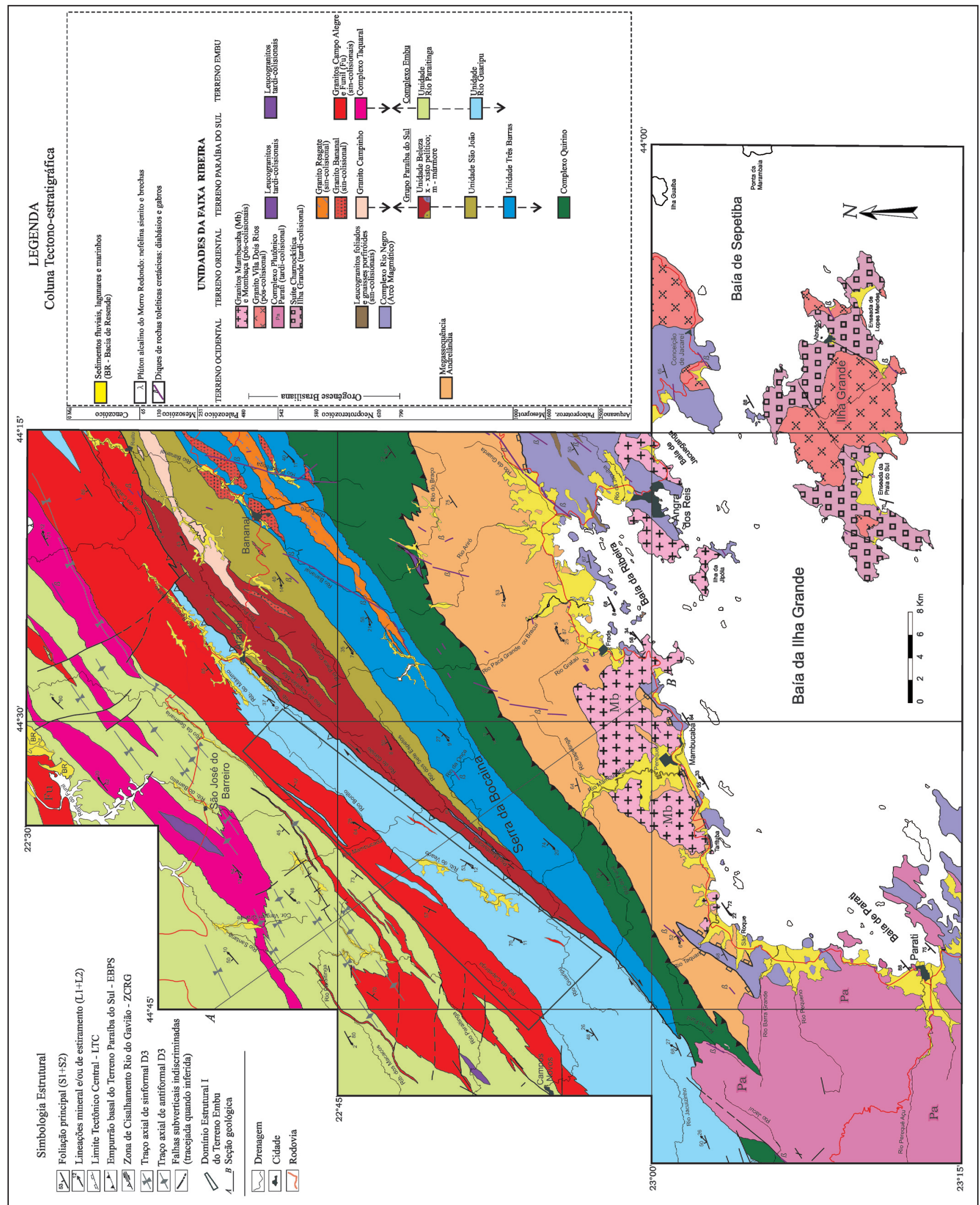

Figura 2 - Mapa geológico da região da Serra da Bocaina e da Baía da Ilha Grande (RJ/ SP). A geologia da Ilha Grande e do litoral entre Angra dos Reis e Conceição de Jacareí (extremo sudeste) foi modificada de Fernandes (2000); e os limites do Granito Funil (a norte), modificado de Pereira (2001). 
entre quartzitos, calcissilicáticas e paragnaisses miloníticos. São freqüentes níveis métricos de granada-biotita gnaisse porfiróide e granada leucognaisses que correspondem a granitóides foliados relacionados à fusão parcial dos metassedimentos na etapa sin-colisional. Vale ressaltar que na área mapeada não ocorrem escamas tectônicas de ortogranulitos do embasamento paleoproterozóico (Complexo Juiz de Fora), que são comumente encontradas no Terreno Ocidental.

Terreno Oriental $\mathrm{O}$ Terreno Oriental aflora junto à costa $\mathrm{e}$ na Ilha Grande, sendo constituído pelos ortognaisses do Complexo Rio Negro, que corresponde ao arco magmático da Faixa Ribeira, e por diversas rochas granitóides das etapas sin a póscolisionais.

COMPLEXO RIO NEGRO Compreende uma variedade de ortognaisses bandados, migmatíticos, destacando-se os seguintes litotipos: (hornblenda)-biotita gnaisse porfiroblástico de composição granítica a granodiorítica e hornblenda-biotita gnaisse tonalítico com enclaves máficos dioríticos. Estas rochas correspondem a plutons pré-colisionais, gerados durante a subducção para leste da litosfera oceânica da Placa São Francisco, num longo período entre 790 e 630 Ma (Tabela 1) (Tupinambá et al., 2000, Heilbron \& Machado, 2003).

GRANITOS FOLIADOS SIN-COLISIONAIS No interior do Complexo Rio Negro são, comumente, encontrados corpos (centimétricos a métricos) semi-concordantes de (hornblenda)biotita gnaisse porfiróide e leucognaisse fino, ambos de composição granítica. As relações estruturais com as rochas encaixantes apontam que esses granitóides foram gerados na etapa sincolisional, pela fusão dos ortognaisses do Complexo Rio Negro. Leucogranitos foliados da região serrana do Estado do Rio de Janeiro, semelhantes aos mapeados na área, forneceram idade U-Pb em zircões de 585 Ma (Tupinambá et al., 2000).

Terreno Paraíba do Sul O Terreno Paraíba do Sul está sobreposto ao Terreno Ocidental, ocupando a faixa central da área de estudo, desde as colinas da região de Bananal (SP), a nordeste, até as áreas elevadas do planalto da Bocaina. São reconhecidos nesse terreno três conjuntos litológicos distintos: ortognaisses do Complexo Quirino, cobertura supracrustal do Grupo Paraíba do Sul e rochas granitóides brasilianas (Fig. 2).

COMPLEXO QUIRINO Esta unidade corresponde ao embasamento do Terreno Paraíba do Sul, é composta por biotita gnaisse migmatítico granítico, predominante na área mapeada, e hornblenda-biotita gnaisse migmatítico granodiorítico a tonalítico, ambos com enclaves centimétricos de diorito e rochas anfibolíticas, além de lentes esverdeadas de composição calcissilicática com tremolita. Freqüentemente intercalado aos ortognaisses ocorre biotita gnaisse porfiróide de composição granítica a granodiorítica, que parece apresentar, por vezes, relações intrusivas com as encaixantes. Valladares et al. (1997) dataram zircões desses ortognaisses obtendo idades $\mathrm{U}-\mathrm{Pb}$ paleoproterozóicas com herança arqueana (Tabela 1). O gnaisse de composição granítica, coletado numa área vizinha à abordada, forneceu idade de $2185 \pm 8 \mathrm{Ma}$, enquanto uma fácies do gnaisse granodiorítico a tonalítico, situado nos arredores de Valença $(\mathrm{RJ})$, resultou em $2169 \pm 3$ Ma. Deve-se observar que, na área estudada, parte do conjunto formado pelo gnaisse granodiorítico a tonalítico e biotita gnaisse porfiróide se assemelham aos ortognaisses encontrados no Terreno Oriental, sendo parecidos, respectivamente, com as rochas do arco magmático do Complexo Rio Negro, e com os granitóides sin-colisionais. Futuras investigações geocronológicas no Complexo Quirino são neces- sárias para datar todo seu conteúdo litológico.

GRUPO PARAÍBA DO SUL A sucessão supracrustal do Grupo Paraíba do Sul, sobreposta ao Complexo Quirino, é subdividida em três associações litológicas, descritas por Almeida et al. (1993) na região de Bananal (SP), porção nordeste da área de estudo. Importante observar que essas três unidades são, progressivamente, truncadas a oeste pela zona de cisalhamento que as limitam da base do Terreno Embu, gerando afunilamento do Terreno Paraíba do Sul (Fig. 2). As três associações litológicas serão relacionadas a seguir, da base para o topo.

a) Unidade Três Barras - composta, principalmente, por biotita gnaisse bandado migmatítico com níveis porfiroblásticos, apresentando intercalações métricas a centimétricas de granada-sillimanita-muscovita-biotita gnaisse/ xisto, lentes de rochas calcissilicáticas e gondito. $\mathrm{Na}$ base desta unidade, o biotita gnaisse é mais migmatítico, além de ocorrerem camadas com hornblenda, o que torna, muitas vezes, difícil delimitar o contato com os ortognaisses do Complexo Quirino. Observa-se também que as intercalações de metapelitos ficam mais freqüentes para sudoeste.

b) Unidade São João - esta associação é constituída principalmente por metapelitos, predominando o turmalina-granadasillimanita-muscovita-biotita gnaisse migmatítico com níveis porfiroblásticos, e intercalações de sillimanita-muscovita-biotita xisto, lentes de rochas calcissilicáticas bandadas ou maciças, gondito, e localmente, mármore, granada anfibolito e quartzitos finos. O contato entre as unidades Três Barras e São João em geral é bem deformado, apresentando, por vezes, fabric milonítico.

c) Unidade Beleza - compreende (muscovita)-biotita gnaisse bandado com muitas intercalações de camadas de (granada)sillimanita-muscovita-biotita xisto e de lentes métricas a centimétricas de rochas calcissilicáticas (bandadas e maciças) e mármore calcítico-dolomítico. Ocorrem também lentes de gondito e quartzitos, cujas características sugerem que, em parte, sejam metacherts. Essa unidade é muito estratificada, alternando metapsamitos, metapelitos e rochas carbonáticas/ calcissilicáticas, e seu contato basal com a Unidade São João é gradacional.

Ocorrem nas três unidades do Grupo Paraíba do Sul pequenos corpos concordantes de leucogranitos foliados com granada e turmalina, relacionados à fusão parcial dos gnaisses e xistos pelíticos. Junto a isto, a marcante presença de muscovita na zona da sillimanita (do tipo fibrolita), associada ao pulso metamórfico principal, posiciona esses metassedimentos numa faixa de transição dentro da fácies anfibolito superior. Este fato não ocorre nos paragnaisses do Terreno Ocidental, onde a muscovita ocorre em menor quantidade e é relacionada ao metamorfismo retrógrado.

GRANITOS FOLIADOS SIN-COLISIONAIS a) Granito Bananal - consiste de corpos lenticulares de dimensões variadas constituído de (granada)-biotita gnaisse porfiroblástico de composição granítica. Possui enclaves de rochas supracrustais, schliren biotíticos, por vezes, com granada e/ou sillimanita, além de contatos gradacionais com os paragnaisses, sendo um granito tipo $\mathrm{S}$, relacionado à fusão das três unidades descritas acima.

b) Granito Resgate - compreende um extenso corpo alongado de granada-turmalina-biotita-muscovita gnaisse/xisto, leucocrático, de composição granítica. Também trata-se de um granito tipo $\mathrm{S}$, bastante deformado, associado a fusão dos paragnaisses da Unidade Três Barras. 
c) Granito Campinho - consiste em hornblenda-biotita gnaisse, por vezes porfirítico, de composição granítica a granodiorítica, com enclaves máficos ricos em hornblenda, de composição tonalítica a quartzo-diorítica. Apresenta características de granito tipo I, sendo um corpo alongado, aparentemente, intrusivo nas unidades São João e Beleza. No entanto, aspectos de campo e petrográficos do granito-gnaisse Campinho se assemelham a litotipos do Complexo Quirino, o que torna seu posicionamento estratigráfico indefinido.

Terreno Embu As rochas deste terreno afloram a norte e a oeste da área estudada, ocupando extensas porções do vale do Paraitinga, e da vertente norte e planalto da Serra da Bocaina. O Terreno Embu encontra-se estruturalmente sobreposto ao Terreno Paraíba do Sul (Fig. 3), e dois conjuntos litológicos são individualizados: cobertura supracrustal e rochas granitóides.

COMPLEXO EMBU O termo Complexo Embu se refere à cobertura supracrustal (Fernandes et al., 1990; Fernandes, 1991), sendo dividido em duas associações litológicas, descritas a seguir da base para o topo, separadas pelo extenso corpo do granito Campo Alegre (Fig. 2).

a) Unidade Rio Guaripu - constituída de sillimanita-muscovita-biotita gnaisse/xisto, ora com granada e/ou turmalina, muscovita-biotita gnaisse fino, com diversas intercalações de lentes de rochas calcissilicáticas, quartzitos micáceos, e, raramente, mármore e anfibolito. Os gnaisses xistosos possuem composição semi-pelítica a pelítica e, normalmente, apresentam leucossomas anatéticos. Esta unidade é truncada a nordeste pelo granito Campo Alegre. A Unidade Rio Guaripu parece corresponder, em parte, às unidades Rio Paraibuna e Redenção da Serra definidas por Fernandes et al. (1990).

b) Unidade Rio Paraitinga - aflora a norte do Granito Campo Alegre e apresenta uma constituição litológica semelhante à unidade basal anterior, predominando um (turmalina)-(granada)sillimanita-muscovita-biotita gnaisse/xisto e (turmalina)-muscovita-biotita gnaisse fino. Porém, além das freqüentes intercalações de rochas calcissilicáticas e quartzitos impuros, agora mais espessos, ocorrem ainda nessa unidade, camadas de estaurolitamuscovita-biotita xisto, granada-hornblenda-biotita gnaisse fino e raras lentes de tremolita xisto. Ocorrem ainda intercalados nos gnaisses xistosos desta unidade, níveis concordantes e centimétricos de turmalinitos, que podem sugerir uma natureza vulcanosedimentar (Pereira, 2001). A Unidade Rio Paraitinga pode ser correlacionada, parcialmente, às unidades Rio Una e Redenção da Serra definidas por Fernandes et al. (1990).

A fusão parcial dos gnaisses xistosos do Complexo Embu, como nas demais sucessões metassedimentares, gerou diversos níveis concordantes de leucogranitos foliados com muscovita, turmalina e granada. Semelhante ao encontrado nas rochas do Grupo Paraíba do Sul, a sillimanita que ocorre no Complexo Embu é do tipo fibrolita, co-existindo com muscovita do caminho metamórfico principal. Porém, a presença de estaurolita em pelitos do topo da Unidade Rio Paraitinga pode indicar metamorfismo um pouco mais baixo, ainda dentro da fácies anfibolito, que o observado na unidade basal Rio Guaripu e no Terreno Paraíba do Sul. Deste modo, o metamorfismo seria do tipo normal, ou seja, diminuindo para as unidades do topo.

ORTOGNAISSES E GRANITÓIDES DO COMPLEXO TAQUA$R A L \quad$ No interior dos metassedimentos da Unidade Rio Paraitinga, ocorrem corpos alongados de ortognaisses e rochas granitóides concordantes denominados de Suíte Taquaral (Heilbron et al. (1995) (Fig. 2). Neste trabalho esta unidade foi redefinida como Complexo Taquaral, que compreende uma variedade de litotipos, sendo subdividido em duas suítes distintas.

A suíte 1 é composta por hornblenda-biotita gnaisses bandados migmatíticos, mesocráticos, localmente porfiríticos, de composição variando de tonalítica a granítica, ricos em enclaves máficos centimétricos dioríticos e tonalíticos. A suíte 2 consiste de biotita leucogranitos foliados, de granulação variando de grossa a fina, cinza claro, por vezes, porfiríticos e com granada. Relações de campo indicam que os leucogranitos da suíte 2 cortam os ortognaisses da suíte 1; corpos métricos de granitos tardios finos a porfiríticos, leucocráticos e com foliação incipiente cortam as duas fácies. Pereira (2001) denominou de Granito São José do Barreiro, que aflora próximo a cidade homônima, um biotita granito porfirítico foliado, aqui incluído na suíte 1 do Complexo Taquaral.

Datações U-Pb em titanitas do Complexo Taquaral foram realizadas por Machado et al. (1996), onde os leucossomas dos gnaisses da suíte 1 forneceram idades de $584 \pm 3 \mathrm{Ma}$, indicando o metamorfismo e anatexia da etapa sin-colisional, enquanto os leucogranitos da suíte 2 resultaram em idade mínima de 553 Ma, confirmando serem mais novos. Neste sentido, a idade dos ortognaisses do Complexo Taquaral continua em aberto, pois pode ser mais antiga que aquela registrada nas titanitas.

GRANITO CAMPO ALEGRE Compreende corpos alongados de direção NE, destacando um de dimensão batolítica, com pelo menos $75 \mathrm{~km}$ de extensão, encaixado entre as unidades Rio Guaripu e Rio Paraitinga do Complexo Embu (Fig. 2). Consiste basicamente de (muscovita)-(granada)-biotita gnaisse porfiróide de composição granítica, com fenocristais de feldspatos de 2 a $6 \mathrm{~cm}$ e, pontualmente, contém hornblenda. Além da fácies porfirítica, subordinadamente, ocorrem níveis de leucogranito equigranular foliado de granulação média. Este granitóide é rico em enclaves lenticulares (xenólitos) de paragnaisses, xistos pelíticos e rochas calcissilicáticas, apresentando, em geral, contatos gradacionais com os metassedimentos, indicando ser granito do tipo S.

$\mathrm{Na}$ área estudada, o Granito Campo Alegre foi denominado, por diversos autores, de Granito Rio Turvo, um granito tipo $\mathrm{S}$ com características semelhantes, porém conforme a definição original, este está encaixado nos metassedimentos do Terreno Ocidental, portanto esse nome não deve ser usado no Terreno Embu.

No extremo norte da área estudada, aflora um corpo denominado de Granito Funil, aqui correlacionado ao Granito Campo Alegre, que possui uma idade U-Pb em zircão de $584 \pm 5 \mathrm{Ma}$ (Pereira, 2001). Resultados similares para esse magmatismo sin-colisional foram reportados por Filipov e Janasi (2001) e Janasi et al. (2003), que apresentaram idades U-Pb em monazita dos seguintes maciços graníticos peraluminosos intrusivos no Complexo Embu: Mauá (588 $\pm 2 \mathrm{Ma})$, Mogi das Cruzes (ca. 580 Ma) e Natividade da Serra (587 $\pm 7 \mathrm{Ma})$.

\section{Granitos Tardi-colisionais}

SUÍTE CHARNOCKÍTICA ILHA GRANDE Compreende um pluton inserido no Terreno Oriental que aflora na Ilha Grande (Fig. 2). Fernandes (2000) caracterizou esta unidade como sendo constituída por rochas contendo, principalmente, feldspatos verdes, hornblenda, biotita, hiperstênio e quartzo, cuja composição varia de charnockítica a charno-enderbítica até jutonítica, com textura equigranular média a grossa ou porfirítica. É comum a presença de enclaves centimétricos de rochas máficas dioríticas e xenólitos de hornblenda-biotita gnaisses do Complexo Rio Negro. Esses charnockitóides apresentam, geralmente, foliação incipiente, interpretada como fluxo magmático ainda sob influência da deformação tardia. A Suíte Charnockítica Ilha Grande parece ser correlacionada aos plutons charnockíticos de 
Ubatuba, no litoral norte paulista, que forneceram idade $\mathrm{Rb} / \mathrm{Sr}$ de 551 \pm 5 Ma (Gasparini e Mantovani, 1979 in Machado Filho et al., 1983).

COMPLEXO PLUTÔNICO PARATI Consiste em um corpo situado no extremo SW da área, originalmente descrito por Castro et al. (1984) e Penha (1989), que aflora desde o litoral de Parati até o planalto da Serra da Bocaina. Compreendendo uma variedade de litotipos, o Complexo Plutônico Parati é formado principalmente por granito porfirítico a, localmente, equigranular, com porções charnockíticas e enclaves dioríticos. Esta unidade intrude todos os quatro terrenos, ou seja, quando a compartimentação tectônica deste segmento da Faixa Ribeira já estava estabelecida (Fig. 2).

A rocha predominante é um (hornblenda)-titanita-biotita granito que apresenta duas fácies, uma porfirítica com fenocristais de K-feldspato de 2 a $4 \mathrm{~cm}$, e outra equigranular média a grossa, leucocrático, com aglomerados de biotita e anfibólio. Assim como o "Charnockito Ilha Grande", esta rocha possui, geralmente, fraca foliação, que torna-se mais marcante nas bordas do corpo, sub-concordante com a foliação das rochas encaixantes. Ocorrem enclaves métricos arredondados a lenticulares de hornblenda-biotita granodiorito equigranular, mesocrático e de rochas máficas dioríticas, ambas com foliação incipiente, além de xenólitos de biotita gnaisse bandado similares ao Complexo Rio Negro.

Localmente, o hornblenda-titanita-biotita granito apresenta uma fácies com feldspatos esverdeados com enclaves, aparentemente discordantes, de rochas dioríticas com ortopiroxênio. Esta fácies esverdeada do "Granito Parati", somada às características composicionais e estruturais, mostra semelhanças com "Charnockito Ilha Grande", sugerindo que sejam análogos. Outro litotipo subordinado desta unidade é um leucogranito branco com biotita, inequigranular e também levemente foliado.

Apófises e veios de granito porfirítico rosa e de biotita granito isotrópico equigranular, que serão tratadas posteriormente, cortam os litotipos descritos acima.

O Complexo Plutônico Parati é posicionado como um batólito tardi-colisional (Tabela 1), pois apresenta uma deformação incipiente e é cortado por granitos mais novos. Porém, assim como a Suíte Charnockítica Ilha Grande, a idade mais precisa desta unidade continua em aberto.

LEUCOGRANITOS Pequenos corpos alongados de leucogranitos afloram no Terreno Paraíba do Sul, especialmente no interior do Complexo Quirino, e no Terreno Embu, destacando o corpo encaixado no Complexo Taquaral próximo a São José do Barreiro (SP) (Fig. 2). Trata-se de rocha homogênea, consistindo basicamente em muscovita-biotita granito cinza claro, equigranular médio. Esses leucogranitos msotram foliação incipiente subvertical, geralmente, associada a zonas de cisalhamento da fase D3, que condicionam o posicionamento desses corpos.

Os leucogranitos são correlatos ao Granito Getulândia, situado em área vizinha do Terreno Paraíba do Sul, sendo classificado como do tipo I fracamente peraluminoso e que forneceu idades U-Pb em monazita, entre 535-527 Ma (Machado et al., 1996; Valladares et al., 2000).

\section{Granitos Pós-colisionais}

GRANITO VILA DOIS RIOS Aflora principalmente na porção central da Ilha Grande e no litoral próximo a Conceição de Jacareí, intrudindo a Suíte Charnockítica Ilha Grande e o Complexo Rio Negro. Esta unidade, bem caracterizada por Fernandes (2000), consiste em biotita granito porfirítico, com fenocristais de K-feldspato rosa de 2 a $5 \mathrm{~cm}$. Contêm enclaves lenticulares de rocha fina, máfica e xenólitos das rochas charnockíticas. Subor- dinadamente apresenta fácies equigranular de granulação média a fina. Este granito ocorre também na forma de apófises e veios no Complexo Plutônico Parati, mas a distinção entre as duas unidades apresentando fácies porfiríticas nem sempre é fácil.

Esta unidade parece correlata ao plúton Pedra Branca (Fernandes, 2000), que aflora a oeste da cidade do Rio de Janeiro, datado em $513 \pm 5 \mathrm{Ma}$, idade U-Pb em monazita e zircão, por Heilbron \& Machado (2003).

GRANITOS MAMBUCABA E MOMBAÇA Compreende os corpos de leucogranitos que afloram na costa da baía da Ilha Grande, relatados originalmente por Castro et al. (1984) e Penha (1989). Consiste em biotita granito cinza claro, contendo titanita, hornblenda, pirita e magnetita como acessórios principais, isotrópico, equigranular médio a ligeiramente porfirítico. Foram observados xenólitos de paragnaisses e rochas calcissilicáticas do Terreno Ocidental, de ortognaisse bandado do Complexo Rio Negro. O corpo do Granito Mambucaba intrude os terrenos Ocidental e Oriental (Fig. 2), sendo que em sua porção superior, na borda do planalto da Bocaina, seu contato com a encaixante e o fluxo magmático são sub-horizontais. Veios e apófises associados a estes granitos cortam o Complexo Plutônico Parati e o Granito Dois Rios.

Machado et al. (1996) dataram o Granito Mangaratiba, um corpo semelhante aos da área estudada, situado a leste na Baía de Sepetiba, que forneceu idade U-Pb em titanita de $492 \pm 15$ Ma. Recentemente, Heilbron \& Machado (2003) dataram zircões de diques de granitos similares na cidade do Rio de Janeiro, que deram idade de $482 \pm 6 \mathrm{Ma}$, caracterizando o período de magmatismo pós-colisional no Terreno Oriental.

OUTROS CORPOS GRANÍTICOS Fechando o quadro do magmatismo brasiliano, ocorrem diversos aplitos graníticos, veios de pegmatito e de quartzo, intrusivos nos granitos tardi a pós-colisionais, muitas vezes encaixados em zonas de cisalhamento dúctil-rúpteis. Cortam as rochas de todos os terrenos tectônicos, porém com maior intensidade no Terreno Oriental.

\section{DEFORMAÇÃO DOS TERRENOS}

Geologia Estrutural da Deformação Principal As estruturas geradas durante a etapa de deformação principal foram estabelecidas no ápice do primeiro estágio colisional da Faixa Ribeira, entre 590 e 560 Ma (Heilbron \& Machado, 2003; Heilbron et al., 2004). No entanto, esta etapa herdou a deformação acumulada desde o estágio pré-colisional, durante a subducçcão oceânica. Assim, duas fases de deformação progressiva (D1+D2) são reconhecidas para esta etapa responsável pela compartimentação tectônica da área de estudo. As estruturas geradas pela fase D1 são, muitas vezes, transpostas pela fase D2, especialmente nas zonas de maior deformação do estágio sin-colisional, por exemplo, nos limites dos terrenos tectônicos. O grau de transposição da fase D1 pela D2 também varia em relação aos terrenos, pois alguns guardam o caráter estrutural da primeira fase. Deste modo, o Terreno Ocidental mostra maior intensidade da deformação D2 que os demais (Eirado et al., 2003), o que é esperado para o compartimento coberto por outros durante a colisão (Fig. 3). A seguir serão descritas as características estruturais (foliações, lineações, dobras e zonas de cisalhamentos) da deformação principal para cada terreno.

TERRENO OCIDENTAL (TOC) A foliação principal (S2+S1) paralela ao bandamento composicional dos metassedimentos apresenta mergulhos de alto ângulo para NW (máximo 335/72) e localmente para SE (Fig. 4a). A foliação neste terreno é comumente milonítica, não somente junto aos contatos tectônicos com o TOR e o TPS. A lineação de estiramento (L2) possui cai- 


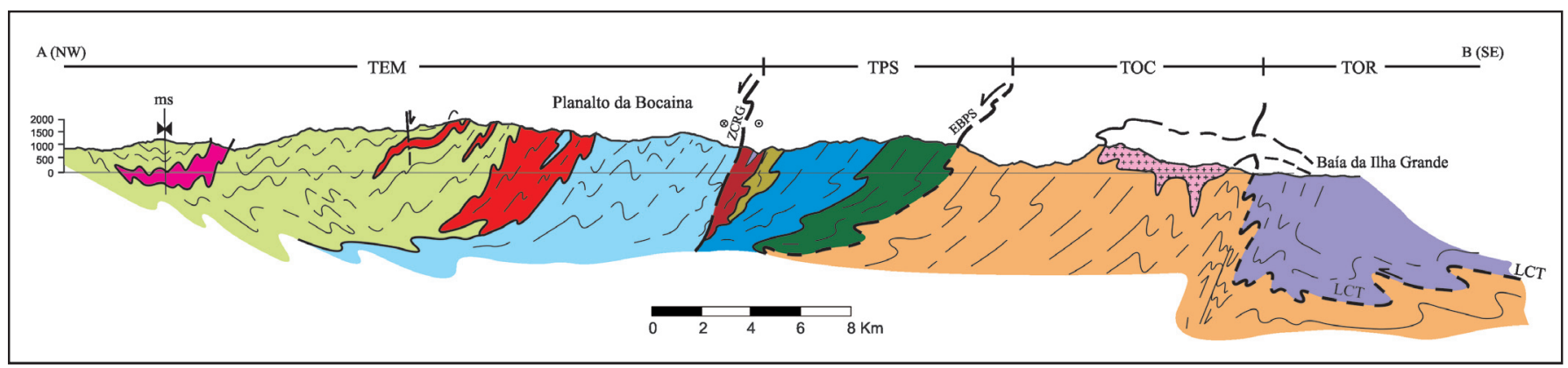

Figura 3 - Perfil geológico-estrutural. Abreviaturas: TEM - Terreno Embu, TPS - Terreno Paraíba do Sul, TOC - Terreno Ocidental, TOR - Terreno Oriental, LTC - Limite Tectônico Central, EBPS - Empurrão Basal do Terreno Paraíba do Sul, ZCRG - Zona de Cisalhamento Rio do Gavião, ms - traço axial da Megassinforma do Paraíba do Sul. Localização e legenda vide mapa geológico (Fig. 2).

mento suave para NE e SW, paralela aos eixos das dobras apertadas a fechadas desta etapa de deformação. As lineações com caimentos down dip para NW são raras.

TERRENO ORIENTAL (TOR) A foliação principal (S1) consiste de uma xistosidade paralela ao bandamento migmatítico dos ortognaisses do Complexo Rio Negro, possuindo mergulhos de médio a alto ângulo para NW (máx. 333/66), localmente, para SE e WSW (Fig. 4b). A foliação só é milonítica junto ao contato com TOC, onde S2 transpõe S1. As lineações mineral e de estiramento possuem caimentos moderados a suaves tanto para SW como para NE. Ocorrem dobras dobradas tanto D1 versus D2, como D2 versus D3; as dobras da fase D2 são fechadas e possuem, geralmente, eixos com caimentos para SW, paralelos as lineações.

O contato com o TOC é uma importante zona de cisalhamento denominada de Limite Tectônico Central (LTC), que corresponde à sutura da Faixa Ribeira (Almeida et al., 1998). Na área mapeada, o LTC apresenta mergulho íngreme para NW e dobrado por D2 e D3. Assim o TOR encontra-se estruturalmente por baixo do TOC (Fig. 3), uma posição invertida, já que o esperado seria um mergulho para SE, com a placa contendo o arco magmático sobreposta à placa subductada. Esse mergulho invertido do LTC pode ser efeito de um endentamento do TOR sob o TOC, ocorrido no ápice da colisão. Por outro lado, esta situação pode ser decorrente dos dobramentos tardi-colisionais D3.

TERRENO PARAÍBA DO SUL (TPS) Assim como observado no TOR, a foliação principal no TPS é S1, uma xistosidade paralela ao bandamento composicional e migmatítico dos paragnaisses e xistos. A foliação S2 também só transpõe S1 nas zonas miloníticas, concentradas no empurrão basal do TPS, que o limita do TOC, e no contato superior com o TEM. Localmente, ocorrem milonitos no contato entre as unidades Três Barras (metapsamitos) e São João (metapelitos), que mostram marcante contraste litológico. A foliação principal S1 e S2 possui mergulhos de médio ângulo para NW (máx. 320/36), expressando, de forma geral, uma estrutura monoclinal (Figs. 3, 4c).

As lineações mineral e de estiramento apresentam caimentos suaves a moderados para SW e NE (máx. 240/06); as lineações com caimento down dip são localizadas. As dobras D1 e D2 são apertadas a fechadas, ambas com eixos paralelos às lineações. Na Unidade Beleza, topo do TPS próximo ao contato com o TEM, ocorrem grandes dobras inclinadas D2. Na porção SW, as unidades do TPS são truncadas pela zona de cisalhamento que limita a base do TEM.

TERRENO EMBU (TEM) A foliação principal (S1) é similar à que ocorre nas rochas do TPS, uma xistosidade nos gnaisses e xistos, e uma clivagem nas rochas quartzíticas. A foliação milonítica $(\mathrm{S} 2+\mathrm{S} 1)$ ocorre no contato com o TPS e, por vezes, no interior dos metassedimentos e no Complexo Taquaral. A característica marcante deste terreno é a variação do mergulho da foliação, ora para NW, ora para SE, devido ao efeito das dobras abertas a fechadas D3 (Figs. 3, 4d, 4e). O TEM foi subdividido em dois domínios estruturais: I e II (Fig. 2). O domínio I abrange as porções centrais dos metassedimentos da Unidade Rio Guaripu (base do TEM) e do Granito Campo Alegre. A foliação possui mergulhos, geralmente, íngremes (máx. 305/78; submáx. $127 / 73$ e 290/36), e as lineações mineral e de estiramento apresentam caimentos suaves a moderados para SW e NE (Fig. 4d). O domínio II, que engloba o restante do TEM, apresenta foliação com mergulhos mais moderados que domínio I (máx.: 316/66; sub-máx.: 135/49 e 143/60) e atitudes das lineações são semelhantes às anteriores (máx. 222/12), porém registrando alguns caimentos down dip para SE (Fig. 4e). No domínio II ocorrem foliações com mergulhos suaves associadas às charneiras de dobras D3 ou a locais onde dobras D2 recumbentes estão preservadas.

Comparando as direções da foliação nos dois domínios estruturais, observa-se que o domínio I mostra strike, em média, entre N20-35E, enquanto no domínio II as atitudes ficam entre N45-50E, semelhantes às encontradas no TPS (Figs. 4d, 4e). Assim, o domínio I apresenta uma inflexão da foliação de $10^{\circ}$ $30^{\circ}$ para norte, gerando um padrão anastomosado ou sigmoidal neste domínio, situado por baixo do domínio II e por cima do TPS. Esta feição estrutural pode estar relacionada ao empilhamento dos terrenos durante a etapa sin-colisional, ou então, devido à reativação de zonas de cisalhamento durante a etapa tardi-colisional.

O contato basal do TEM com o TPS é uma estreita faixa milonítica, aqui denominada de Zona de Cisalhamento Rio do Gavião (ZCRG), em referência a um tributário do rio Mambucaba situado no Planalto da Bocaina, encaixado nesta estrutura (Fig. 2). A ZCRG possui mergulho subvertical para NW e lineação de estiramento com caimento suave, geralmente, para SW. Os poucos indicadores cinemáticos observados sugerem movimento oblíquo destral, com topo descendo para norte. Deste modo, a ZCRG é aqui interpretada como um empurrão oblíquo de alto ângulo, desenvolvido na fase D2 (Fig. 3). Esta zona revela sinais de reativações dúcteis (fase D3) e, notadamente, rúpteis (fase D4 e/ou posterior), já que ocorrem texturas cataclásticas e estrias de falhas, superpostas ao fabric milonítico D2. Importante ressaltar que a ZCRG corresponde à continuidade da Zona de Cisalhamento de Cubatão (Sadowski, 1991), limite sul do TEM.

Concluindo, percebe-se que nos quatro terrenos as lineações 


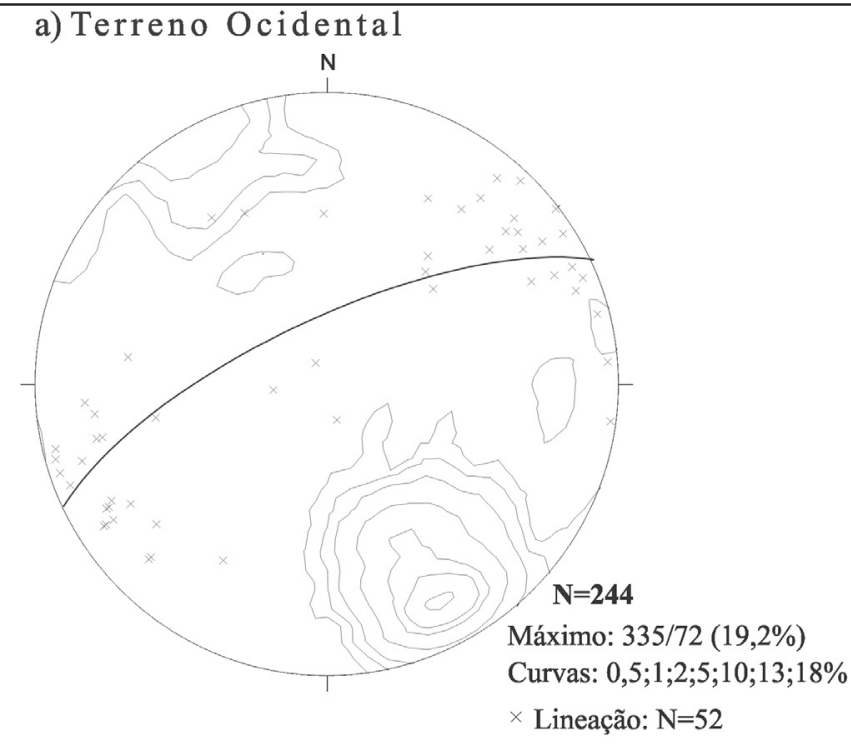

c) Terreno Paraíba do Sul

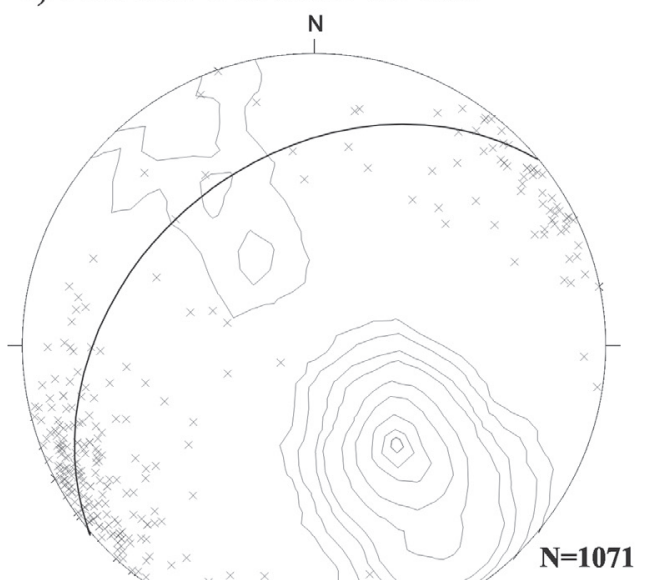

Máximo: 320/36 (16,7\%)

Curvas: 0,$5 ; 1 ; 2 ; 3 ; 6 ; 9 ; 13 ; 15 ; 16 \%$

$\times$ Lineação: $\mathrm{N}=273$

máx: $240 / 6(15,7 \%)$

e) Terreno Embu- Domínio II

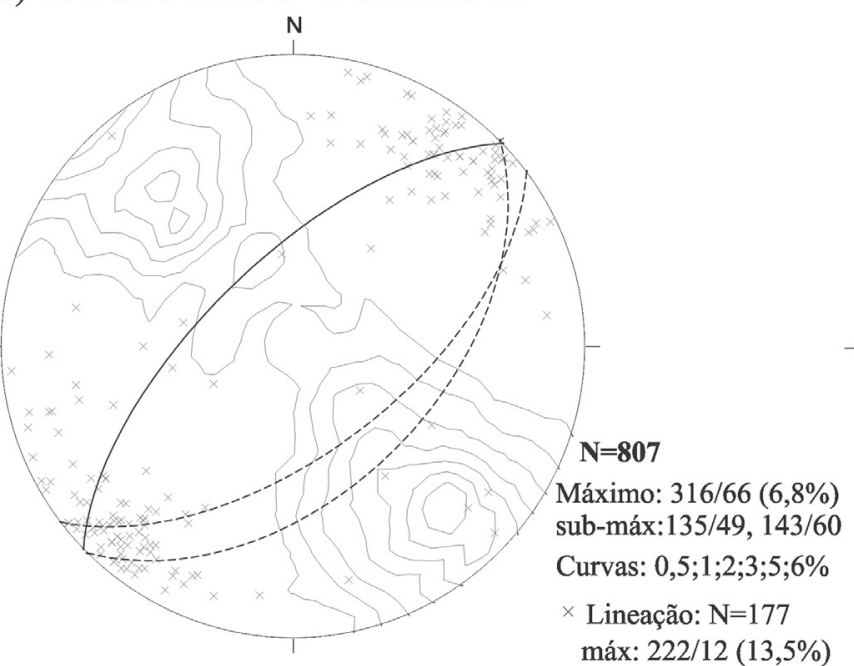

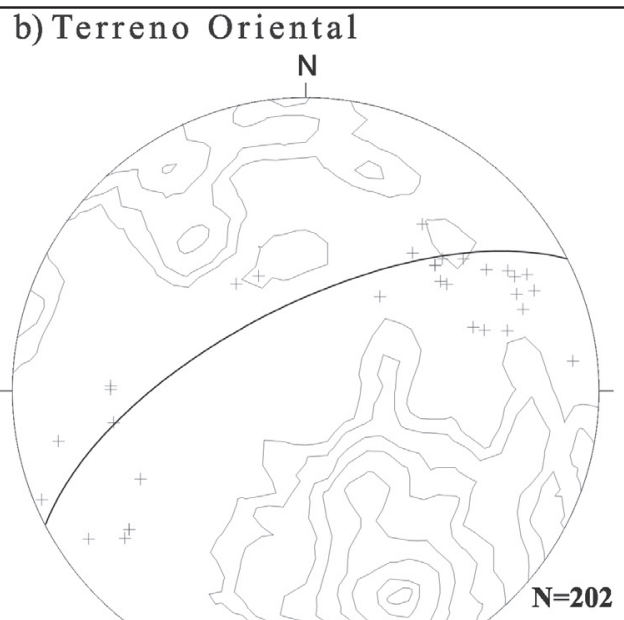

Máximo: 333/66 (11,4\%)

Curvas: 0,$5 ; 1 ; 2 ; 3 ; 5 ; 7 ; 10 ; 11 \%$

× Lineação: $\mathrm{N}=32$

d) Terreno Embu- Domínio I

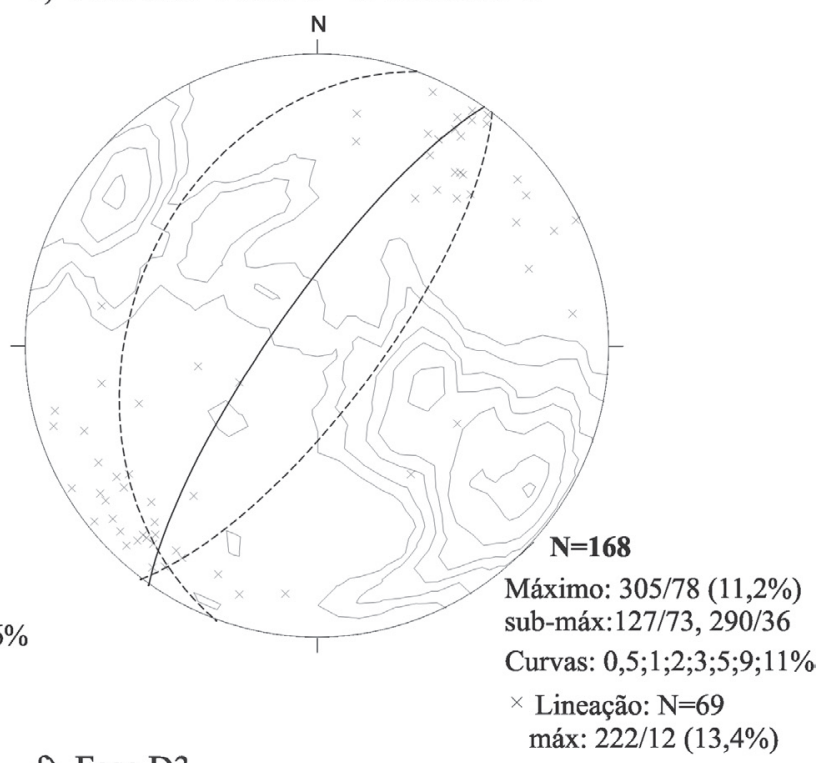

f) Fase D3

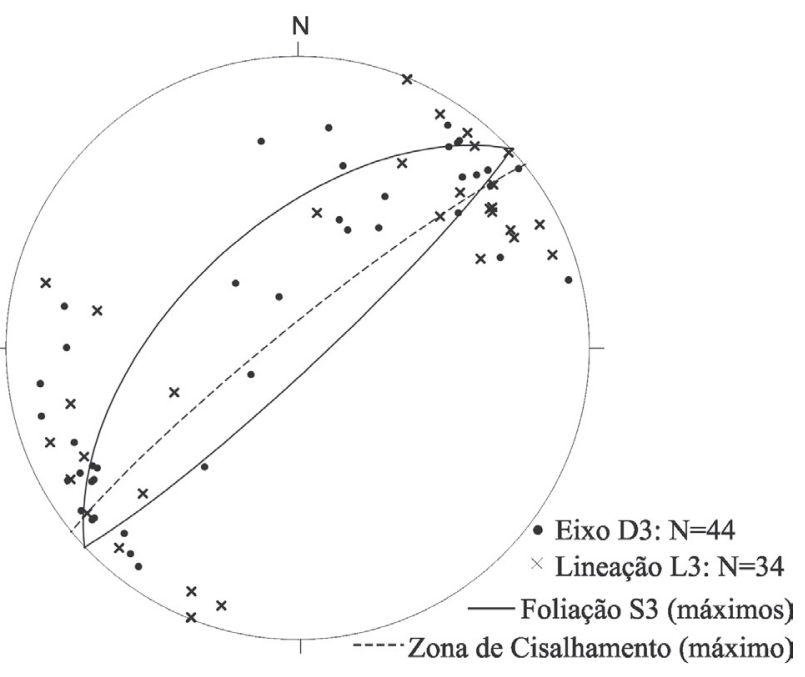

Figura 4 - Estereogramas de pólos da foliação principal $(S 1+S 2)$ e de lineação mineral/ estiramento $(L 1+L 2)$, contendo os traços dos planos máximos (linha cheia) e sub-máximos (linha tracejada) da foliação: (a) Terreno Oriental; (b) Terreno Ocidental; (c) Terreno Paraiba do Sul; (d) Domínio I do Terreno Embu; (e) Domínio II do Terreno Embu. (f) Estereograma de lineações e eixos de dobras da fase D3 para todos os terrenos, e traços dos planos máximos da foliação S3 (linha cheia) e de zona de cisalhamento D3 (linha tracejada). Rede equi-área, hemisfério inferior. 
de estiramento apresentam caimentos suaves e baixa obliqüidade com a foliação principal. Aliado ao empilhamento estrutural dos terrenos (fig. 3), este comportamento sugere indicar a atuação de movimentos transpressivos com compressão NW-SE e estiramento NE-SW, não refletindo transporte direcional predominante (Eirado et al., 2003).

Geologia Estrutural da Deformação Tardi e Pós-colisional As estruturas geradas na etapa de deformação principal (D1+D2) foram, posteriormente, deformadas e reativadas nas fases desenvolvidas após o ápice colisional, quando os quatro terrenos já estavam amalgamados. São reconhecidas estruturas vinculadas a duas fases de deformação distintas, relacionadas às etapas tardi e pós-colisional.

FASE D3 Em todos os quatro terrenos abordados, as dobras são as estruturas características desta fase de deformação. Consistem em sinformais e antiformais abertos a fechados, com planos axiais íngremes, normalmente, subparalelos à foliação principal, e eixos com caimentos suaves para NE ou SW (Fig. 4f). Comparado aos outros terrenos, o TEM mostra maior intensidade dos dobramentos D3, especialmente o domínio estrutural II (Figs. 2, 3, 4e), na porção norte da área, setor associado à zona de charneira da Megassinforma do Paraíba do Sul, uma estrutura de caráter regional (Heilbron et al., 1991).

A foliação S3 ocorre, localmente, como clivagem de plano axial, principalmente, nos litotipos xistosos e quartzíticos. De modo geral, os mergulhos de S3 são íngremes para SE ou de médio a alto ângulo para NW (Fig. 4f). Esta variação, junto com as observações de campo, indica a tendência assimétrica das dobras D3, relacionada ao flanco sul da Megassinforma do Paraíba do Sul. As lineações L3 consistem em lineação de crenulação nas rochas xistosas, paralela aos eixos D3, e lineação de interseção com a foliação principal. Foliação milonítica e lineação de estiramento da fase D3 ocorrem, localmente, no interior das zonas de cisalhamento subverticais de direção NE e paralelas aos planos axiais das dobras D3 (Fig. 4f).

São observados pequenos corpos e veios de leucogranitos (tardi-colisionais) encaixados nas zonas de cisalhamento D3, como aqueles relatados anteriormente no TPS e TEM. Na borda norte do planalto da Bocaina, dentro da Unidade Rio Paraitinga do TEM, as zonas de cisalhamento D3 são dúctil-rúpteis, geralmente associadas às charneiras de dobras desta fase, e apresentam marcante rejeito vertical. Estas zonas mostram sinais de reativações rúpteis posteriores, devido à presença de espelhos de falhas com estrias. Por fim, os limites tectônicos dos terrenos, principalmente, o LTC e a ZCRG, também apresentam registros de reativação durante a fase $\mathrm{D} 3$.

FASE D4 As estruturas típicas da fase D4 são zonas de cisalhamento dúctil-rúpteis, subverticais, de direções NW e, subordinadamente, NE, que mostram movimentação, geralmente, oblíqua (destral e sinistral) com importante rejeito normal. Nestas zonas de cisalhamento foram observados pseudotaquilitos e texturas cataclásticas, denotando a transição para um nível crustal rúptil. Como citado anteriormente, a fase D4 reativou as zonas de cisalhamento geradas nas fases principal (p. ex. ZCRG) e tardia (D3). São freqüentes os veios de leucogranitos, pegmatitos e quartzo encaixados nas zonas de cisalhamento. Esta fase de deformação está relacionada à etapa pós-colisional, ou seja, ao colapso do Orógeno Ribeira.

CORRELAÇÕES REGIONAIS E PROBLEMAS EM ABERTO Para concluir este trabalho, serão feitas considerações e levantadas algumas questões com o intuito de integrar a área de estudo ao contexto tectônico do segmento central da
Faixa Ribeira (Fig. 1).

Dos quatro terrenos tectônicos que ocorrem na região da Serra da Bocaina e Baía da Ilha Grande, dois deles - Ocidental e Oriental - apresentam posicionamento tectônico mais estabelecido. $\mathrm{O}$ Terreno Ocidental é relacionado à margem retrabalhada da paleoplaca São Francisco, que na área estudada é representado pelos metassedimentos correlatos a Megassequência Andrelândia e está inserido no Domínio Juiz de Fora, um sistema de empurrões que corresponde à escama tectônica superior deste terreno (Heilbron et al., 2000; Trouw et al., 2000). Por sua vez, o Terreno Oriental, que corresponde em parte à Microplaca Serra do Mar (Campos Neto \& Figueiredo, 1995), constitui outra placa que alojou o arco magmático do segmento central do Orógeno Ribeira, durante a subducção oceânica da Placa São Francisco (Tupinambá et al., 2000; Heilbron \& Machado, 2003).

Por outro lado, a origem e a paleogeografia dos terrenos Paraíba do Sul e Embu, que cavalgam o Terreno Ocidental (Fig. 3), ainda são questões em aberto. O Terreno Paraíba do Sul é composto por embasamento paleoproterozóico (Complexo Quirino), cobertura metassedimentar (Grupo Paraíba do Sul) e granitóides brasilianos. Já o Terreno Embu, na região estudada, é constituído por cobertura supracrustal (Complexo Embu) e granitóides brasilianos (Tabela 1). Assim, a primeira questão a respeito da natureza dos terrenos Embu e Paraíba do Sul, é se eles estão associados a uma mesma (micro) placa ou não?

Campos Neto (2000) sugere que as rochas metassedimentares dos complexos Embu e Paraíba do Sul estariam inseridos no Terreno Juiz de Fora, correspondendo a sucessões relacionadas ao arco magmático neoproterozóico. No entanto, como referido acima, interpretamos que o Terreno (ou Domínio) Juiz de Fora consiste de um segmento do Terreno Ocidental, e seu conjunto metassedimentar, bem como o embasamento, não se assemelham àqueles encontrados nos terrenos Paraíba do Sul e Embu.

Em relação ao conteúdo litológico, as sucessões supracrustais dos dois terrenos são semelhantes, excetuando a maior freqüência de quartzitos nas unidades do Complexo Embu, e presença marcante de mármores nas unidades superiores do Grupo Paraíba do Sul. Em ambos os terrenos, predominam gnaisses e xistos semi-pelíticos a pelíticos com intercalações de rochas calcissilicáticas. Poderiam estas associações litológicas corresponder a uma mesma sucessão supracrustal com mudanças de litofácies durante a sedimentação? O contato tectônico entre elas também poderia corresponder a uma discordância?

Quanto ao embasamento das coberturas supracrustais, o Terreno Paraíba do Sul apresenta os ortognaisses do Complexo Quirino, porém, em relação ao Terreno Embu, não foram identificadas na área mapeada rochas ortoderivadas que correspondam claramente ao seu embasamento pré-1,8 Ga. No entanto, na região vizinha do leste do estado de São Paulo, Fernandes (1991) indicou os ortognaisses do Complexo Rio Capivari como embasamento do Complexo Embu. Estes ortognaisses foram datados por Babinski et al. (2001), na região ao sul de São José dos Campos (SP), que obtiveram idade U-Pb em zircões de 2004 $13 \mathrm{Ma}$, com herança arqueana. Se estas rochas correspondem ao embasamento paleoproterozóico do Terreno Embu, qual a afinidade delas com o Complexo Quirino (que possui idade semelhante)? Esta questão deve ser alvo de investigações futuras.

A discussão em torno da ambientação tectônica dos terrenos Paraíba do Sul e Embu, leva a indagar se eles poderiam estar vinculados à placa do Terreno Oriental. Heilbron \& Machado (2003) sugeriram que a sucessão metassedimentar do Terreno Paraíba do Sul corresponderia a bacia ante-arco do Terreno Oriental. Como já relatado anteriormente, no interior do Complexo Quirino ocorrem ortognaisses semelhantes às rochas do Complexo Rio Negro, que afloram no litoral da Baía da Ilha Grande. Outra unidade do Terreno Paraíba do Sul que deve 
ser melhor investigada é o Granito Campinho, um hornblenda gnaisse com enclaves máficos encaixado nos metassedimentos (Fig. 2). Este corpo foi aqui interpretado como um granitóide sin-colisional, porém existe a possibilidade dele ser correlato às rochas do arco magmático ou mesmo aos ortognaisses paleoproterozóicos do Complexo Quirino. Assim, a ampliação das pesquisas geocronológicas e geoquímicas nesses ortognaisses é fundamental para esclarecer o elo entre os terrenos Paraíba do Sul e Oriental.

No contexto do Terreno Embu, os ortognaisses do Complexo Taquaral que ocorrem intercalados nos metassedimentos (Fig. 2) possuem posicionamento ainda indefinido. Estes ortognaisses podem corresponder apenas a granitóides intrusivos da etapa sin-colisional, ou podem constituir rochas ígneas pré-colisionais, ou seja, correlatas a um arco magmático (p.ex. Complexo Rio Negro). A possibilidade dos ortognaisses do Complexo Taquaral representarem o embasamento paleoproterozóico, também não pode ser ainda descartada. Em uma área a SW da cidade de São Paulo, ortognaisses granodioríticos a tonalíticos encaixados no Complexo Embu foram datados por Cordani et al. (2002), fornecendo idade U-Pb em zircões de ca. $810 \mathrm{Ma}$. Segundo estes autores, os ortognaisses possuem características isotópicas de arco magmático continental, correspondendo a estágios antigos da subducção oceânica. Este resultado é próximo às idades de ca. $790 \mathrm{Ma}$ obtidas em rochas do arco magmático Rio Negro (Terreno Oriental), na cidade do Rio de Janeiro (Heilbron \& Machado, 2003). Portanto, estudos confrontando as rochas dos arcos magmáticos dos terrenos Embu e Oriental tornam-se necessários.

Idades neoproterozóicas similares $(790 \pm 20 \mathrm{Ma})$ fornecidas por monazitas de paragnaisses registram metamorfismo de fácies anfibolito do Complexo Embu (Vlach, 2001). Este autor sugere que esse pulso metamórfico estaria relacionado a uma etapa de colisão mais antiga da Orogênese Brasiliana, ainda não encontrada em outros setores da Faixa Ribeira. Por outro lado, esse importante evento magmático-metamórfico (ca. 810$790 \mathrm{Ma}$ ) registrado no Terreno Embu, talvez esteja associado somente à evolução do arco magmático, incluindo o metamorfismo nas rochas metassedimentares, não definindo, portanto, a etapa colisional que envolveu este terreno. Neste sentido, as coberturas supracrustais do Terreno Embu realmente poderiam corresponder tanto às sucessões da margem passiva que alojou o arco magmático, como às bacias marginais contemporâneas a instalação deste arco. As mesmas possibilidades são válidas para o Terreno Paraíba do Sul, mesmo que suas origens correspondam a placas distintas.

Agradecimentos Aos professores Claudio Valeriano, Miguel Tupinambá, Claudia Valladares e Beatriz Duarte pelas contribuições ao longo dos estudos relacionados a este artigo. Aos diversos alunos de graduação da UERJ que participaram no desenvolvimento das pesquisas, destacando Raquel Theodoro, Maite de Medeiros, Alexandre Brugger e Manollo Barros. Ao geólogo Guilherme Fernandes pelos dados da Ilha Grande gerados na sua dissertação de mestrado. Aos dois relatores anônimos que contribuíram para a finalização deste artigo. À Fátima Dios pela revisão do abstract. À Sheilla de Souza e Miguel Buck pela edição das figuras do mapa e perfil geológico. Ao Walter Agripino pelo apoio durante os trabalhos de campo.

Ao TEKTOS - Grupo de Pesquisa em Geotectônica e à Faculdade de Geologia da UERJ pela infra-estrutura utilizada no desenvolvimento desta pesquisa. Ao CNPq, FAPERJ e FINEPCTPetro pelo suporte financeiro aos estudos realizados, e à CAPES pela concessão de bolsa de doutorado para o autor.

\section{Referências}

Almeida J.C.H., Silva L.G.E., Valladares C.S. 1993. O Grupo Paraíba do Sul e rochas granitóides na região de Bananal (SP) e Rio Claro (RJ): uma proposta de formalização litoestratigráfica. In: SBG, Simp. Geol. Sudeste, 3, Rio de Janeiro, Atas, p.155-160.

Almeida J.C.H., Tupinambá M., Heilbron M. Trouw R. 1998. Geometric and kinematic analysis at the Central Tectonic Boundary of the Ribeira Belt, Southeastern Brazil. In: SBG, Congr. Bras. Geol., 39, Belo Horizonte, Anais, p.32.

Babinski M., Tassinari C.C.G., Nutman A.P., Sato K., Martins P.R., Iyer S.S. 2001. U/Pb shrimp zircon ages of migmatites from the basement of the Embu Complex, Ribeira Fold Belt, Brazil: indications for 1.4-1.3 Ga Pb-Pb and Rb-Sr "isochron" ages of no geological meaning. In: Simp. Sudamer. Geol. Isot., 3, Pucon, Abst., 9.

Campos Neto M.C. 2000. Orogenic systems from southwestern Gondwana - an approach to Brasiliano-Panafrican cycle and orogenic collage in southeastern Brazil. In: U.G. Cordani, E.J. Milani, A Thomaz Filho, D.A. Campos (eds). Tectonic Evolution of South America. 31 ${ }^{\text {st }}$ Int. Geol. Congr., Rio de Janeiro, p.335-365.

Campos Neto M.C. \& Figueiredo M.C.H. 1995. The Rio Doce Orogeny, southeastern Brazil. J. S. Am. Earth Sci., 8:143-162.

Castro H.M., Rocha R.L.S., Sperling E.V., Baltazar O.F. 1984. Geologia das folhas Mangaratiba, Ilha Grande, Cunhambebe, Angra dos Reis, Rio Mambucaba/ Campos de Cunha, Parati, Cunha, Pinciguaba e Juatinga - RJ. In: SBG, Congr. Bras. Geol., 33, Rio de Janeiro, Anais, p.2355-2367.

Cordani U.G., Coutinho J.M.V., Nutman A.P. 2002. Geochronological constraints on the evolution of the Embu Complex, São Paulo, Brazil. J. S. Am. Earth Sci., 14:903-910.

Eirado L.G., Barros M., Almeida J., Heilbron M. 2003. Os terrenos tectônicos da Faixa Ribeira na região da Serra da Bocaina e Baía da
Ilha Grande, Sudeste do Brasil. In: SBG, SNET, 9, Armação dos Búzios, Boletim Res., p.95-98.

Fernandes A.J. 1991. As unidades regionais do Complexo Embu e seu embasamento, no leste do Estado de São Paulo. In: SBG, Simp. Geol. Sudeste, 2, São Paulo, Atas, p.501-508.

Fernandes A.J., Campos Neto M.C., Figueiredo M.C.H. 1990. O Complexo Embu no leste do Estado de São Paulo: limites e evolução geológica. In: SBG, Congr. Bras. Geol., 36, Natal, Anais, p.27552763.

Fernandes G.A. 2000. Contribuição ao Entendimento Geológico do Terreno Oriental da Faixa Ribeira na Baía da Ilha Grande, litoral sul fluminense, RJ. Dissertação de Mestrado, Faculdade de Geologia, Universidade do Estado do Rio de Janeiro, Rio de Janeiro, p.108.

Filipov M. \& Janasi V.A. 2001. The Mauá granitic massif, Central Ribeira Belt, São Paulo: Petrography, geochemistry and U-Pb dating. Rev. Bras. Geoc., 31:341-348.

Heilbron M. \& Machado N. 2003. Timing of terrane accretion in the Neoproterozoic-Eopaleozoic Ribeira orogen (se Brazil). Precambrian Res., 125:87-112.

Heilbron M., Valeriano C.M., Almeida J.C.H., Tupinambá M. 1991. A megassinforma do rio Paraíba do Sul e sua implicação na compartimentação tectônica do setor central da Faixa Ribeira. In: SBG, Simp. Geol. Sudeste, 2, Atas, p.519-526.

Heilbron M., Valeriano C., Valladares C.S., Machado N. 1995. A orogênese brasiliana no segmento central da Faixa Ribeira, Brasil. Rev. Bras. Geoc., 25(4):249-266.

Heilbron M., Mohriak W., Valeriano C.M., Milani E., Almeida J.C.H., Tupinambá M. 2000. From Collision to Extension: The Roots of the Southeastern Continental Margin of Brazil. In: M. Talwani \& W. Mohriak (eds.) Atlantic Rifts and Continental Margins, Geophysical 
Monograph Series, 115, American Geophysical Union, pp. 1-34.

Heilbron M., Pedrosa-Soares A.C., Campos Neto M., Silva L.C., Trouw R.A.J., Janasi V. 2004. A Província Mantiqueira. In: V. MantessoNeto, A. Bartorelli, C.D.R. Carneiro, B.B. Brito-Neves (orgs.) Geologia do Continente Sul-Americano: Evolução da Obra de Fernando Flávio Marques de Almeida, São Paulo, Beca, pp. 203-234.

Janasi V.A., Alves A., Vlach S.R.F., Leite R.J. 2003. Granitos peraluminosos da porção central da Faixa Ribeira, estado de São Paulo: sucessivos eventos de reciclagem da crosta continental no Neoproterozóico. Geol. USP Série Cient., 3:13-24.

Machado Filho L., Ribeiro M.W., Gonzalez S.R., Schenini C.A., Santos Neto A., Palmeira R.C.B., Pires J.L., Teixeira W., Castro H.E.F. 1983. Folhas SF. 23/24 Rio de Janeiro/Vitória, Geologia. Projeto RADAMBRASIL, MME, Rio de Janeiro, v.32, p.27-304.

Machado, N., Valladares, C., Heilbron, M., Valeriano, C., 1996. U-Pb geochronology of the Ribeira Belt (Brazil) and implications for the evolution of the Brazilian Orogeny. Precambrian Res., 79: $347-$ 361.

Paciullo F.V.P., Ribeiro A., Andreis R.R., Trouw R.A.J. 2000. The Andrelândia Basin, a Neoproterozoic intraplate continental margin, southern Brasília belt. Rev. Bras. Geoc., 30(1):200-202.

Penha H.M. 1989. Geologia dos corpos granitóides do litoral oeste do Estado do Rio de Janeiro. In: SBG, Simp. Geol. Sudeste, 1, Rio de Janeiro, Boletim Res., p.165-166.

Pereira R.M. 2001. Caracterização geocronológica, geoquímica, geofisica e metalogenética de alguns plutonitos graníticos da região do médio vale do rio Paraíba do Sul e alto rio Grande, segmento central da Faixa Ribeira. Tese de Doutoramento, Instituto de Geociências, Universidade Federal do Rio de Janeiro, Rio de Janeiro, $213 \mathrm{p}$.

Pereira R.M., Ávila C.A., Moura C.A.V. 2001. Geologia da região entre Resende e São José do Barreiro e idade ${ }^{207} \mathrm{~Pb} /{ }^{206} \mathrm{~Pb}$ do granito Funil, segmento central da Faixa Ribeira (RJ-SP), Brasil. Geociências, 20 (1/2):37-48.

Sadowski G.R. 1991. A megafalha de Cubatão. Bol. IG-USP, Sér. Cient.
22:15-28.

Schmitt R.S., Trouw R.A.J., Van Schmus W.R., Pimentel M.M. 2004. Late amalgamation in the central part of West Gondwana: new geochronological data and the characterization of a Cambrian collisional orogeny in the Ribeira Belt (SE Brazil). Precambrian Res., 133:29-61.

Trouw R.A.J., Heilbron M., Ribeiro A., Paciullo F.V.P., Valeriano C.M., Almeida J.C.H, Tupinambá M, Andreis R.R. 2000. The central segment of the Ribeira Belt. In: U.G. Cordani, E.J. Milani, A. Thomaz Filho, D.A. Campos (eds). Tectonic Evolution of South America. $31^{\text {st }}$ Int. Geol. Congr., Rio de Janeiro, p.287-310.

Tupinambá M. 1999. Evolução tectônica e magmática da Faixa Ribeira na Região Serrana do Estado do Rio de Janeiro. Tese de Doutoramento, Instituto de Geociências, Universidade de São Paulo, São Paulo, $221 \mathrm{p}$.

Tupinambá M., Teixeira W., Heilbron M. 2000. Neoproterozoic western Gondwana assembly and subduction related plutonism: the role of the Rio Negro Complex in the Ribeira belt. Rev. Bras. Geoc. 30(1):007-011.

Valladares C.S., Duarte B.P., Heilbron M. 2000. The tectono-magmatic evolution of the Occidental terrane and the Paraíba do Sul klippe within the Neoproterozoic Ribeira orogenic belt, southeastern Brazil. Rev. Bras. Geoc., 30(1):001-006.

Valladares C.S., Heilbron M., Figueiredo M.C.H., Teixeira W. 1997. Geochemistry and geochronology of Paleoproterozoic gneissic rocks of the Paraíba do Sul Complex (Quirino unit), Barra Mansa Region, Rio de Janeiro, Brasil. Rev. Bras. Geoc., 27(1):111-120.

Vlach S.R.F. 2001. Micropobe monazite constraints for an early (ca. 790 Ma) Brasiliano orogeny: the Embu terrane, southeastern Brazil. In: South Am. Symp. Isot. Geol., 3, Pucón, Ext. Abst., p. 265-268.

Manuscrito A1590

Aprovado em 03 de novembro de 2006 